\title{
Technology-mediated communication with patients: WhatsApp Messenger, e-mail, patient portals. A challenge for pediatricians in the digital era
}

\author{
Laura Krynski, M.D. ${ }^{a}$ and Guillermo Goldfarb, M.D. ${ }^{a, b}$ \\ Collaborator: Ignacio Maglio, Esq. ${ }^{\circ}$
}

\begin{abstract}
The digital revolution will have a profound impact on how physicians and health care delivery organizations interact with patients and the community. Primary pediatric care has been historically known in our setting because pediatricians are widely available for consultations. The rapid development of information and communication technologies and their impact on people's life pose a new challenge for pediatricians in relation to the way they communicate with the families of the patients they see.

The objective of this article is to analyze the available channels for communication mediated by information and communication technologies with patients, and to propose recommendations for their adequate use.

Key words: telemedicine, information technology, mobile applications, Internet.
\end{abstract}

http: / / dx.doi.org/10.5546/ aap.2018.eng.e554

a. Subcommittee of Information and Communication Technologies, Argentine Society of Pediatrics.

b. Hospital de Niños

"Dr. Ricardo Gutiérrez."

c. Department of Medical-Legal Risk, Hospital "Fco. J. Muñiz," Area for the Promotion of Rights of FundaciónHuésped. Autonomous City of Buenos Aires.

E-mail address:

Guillermo Goldfarb:

M.D.: guille.goldfarb@ gmail.com

Funding:

None.

Conflict of interest: None.

Received: 11-7-2017 Accepted: 1-22-2018
To cite: Krynski L, Goldfarb G. Technologymediated communication with patients: WhatsApp Messenger, e-mail, patient portals. A challenge for pediatricians in the digital era. Arch Argent Pediatr 2018;116(4):e554-e559.

These (technological) trends are likely to induce cultural changes in the delivery of care even more revolutionary than any restructuring that is going on today. On line, computer-assisted communication between patients and medical databases and between patients and physicians promises to replace a substantial amount of care now delivered in person.

Kassirer J, NEJM 1995;332:52-4

\section{INTRODUCTION}

"The digital revolution will have a profound impact on how physicians and health care delivery organizations interact with patients and the community. Over the coming decades, face-to-face patient-doctor contacts will become less common, and exchanges between patients and doctors will increasingly be mediated by electronic devices." ${ }^{1}$

Primary pediatric care has been historically known because pediatricians are widely available for consultations. This has always been part of the customs and traditions, and there are no predetermined regulations to frame this type of communication. The means for this communication to take place have changed over time along with the advances in technological tools.

Telephones were fundamental until the development of pagers around 1950. The first short message service (SMS) signal was sent in 1992; since then, electronic messaging has grown exponentially and, at present, more than 20 trillion messages are sent every day.

Recently, mass market, low cost instant messaging services (WhatsApp Messenger, Skype, Telegram, Messenger, etc.) have practically replaced all electronic media used before thanks to the wide availability of smartphones worldwide.

A recent study conducted in the United Kingdom indicated that 98.9\% of physicians used a smartphone. ${ }^{2}$

In Argentina, according to the National Survey on Access to and Use of Information and Communication Technologies (Encuesta Nacional sobre Acceso y Uso de Tecnologías de la Información y la Comunicación, ENTIC), conducted by the Instituto Nacional de Estadística y Censos, INDEC in July 2015, there are 45 million mobile phones, i.e., approximately 1.17 phones / person. ${ }^{3}$ 
Based on an ongoing study by the Subcommittee of Information and Communication Technologies of the Argentine Society of Pediatrics on the use of information and communication technologies (ICTs) among Argentine pediatricians, out of 2530 surveyed pediatricians, $76.9 \%$ stated that they used a messaging application to communicate with their patients. WhatsApp Messenger was the preferred communication tool to interact with the patients among almost $77 \%$ of participants, followed by e-mails and SMS messages (Table 1).

It has been estimated that a primary care physician who sees 2000 patients receives approximately 50 daily "requests." Of these, 2030 could be managed with a mutually convenient electronic communication system. ${ }^{4}$

The regulation of electronic messages is still confusing: although communication is now more secure, there is a risk for a breach of protected information. ${ }^{5}$

We will analyze available communication channels in detail.

\section{Instant messaging applications}

Instant messaging is a form of real time communication between two or more people. In the beginning, it was used to send and receive texts; now, it admits voice messages, images, videos, and files.

The most renowned applications include WhatsApp Messenger, Telegram, Hangouts, Facebook Messenger, and Skype.

WhatsApp Messenger is a mobile instant messaging application launched in 2009 that quickly became accessible to all and is now the most widely used application by all age groups for different purposes. ${ }^{6}$

TABLE 1. Tools mediated by information and communication technologies used by Argentine pediatricians to communicate with patients (Survey on the use of information and communication technologies among pediatricians offering office visits in Argentina. 2017)

\begin{tabular}{lcc}
\hline & Answer options & Answers \\
\hline WhatsApp Messenger & $76.99 \%$ & 1947 \\
E-mail & $32.15 \%$ & 813 \\
SMS (text messages) & $32.15 \%$ & 813 \\
I do not offer consultations & & \\
via any of these means & $17.52 \%$ & 443 \\
Facebook & $6.13 \%$ & 155 \\
Twitter & $0.32 \%$ & 8 \\
\hline
\end{tabular}

Total number of survey respondents: 2530.
Its main advantages are that it is a simple, inexpensive, and effective means of communication. It allows to exchange images and files without size limit. The use of WhatsApp Messenger increases on a daily basis, currently with more than 1 billion active users, which accounts for 55 billion messages, 1 billion videos, and 4.5 billion images sent every day. ${ }^{7}$

In the medical field, it is mainly used for:

- Communication among physicians to discuss clinical cases.

- Groups that share interests, either in relation to a single or multiple disciplines to facilitate communication and discussion or decisionmaking. ${ }^{8,9}$

- Teleconsultation.

- Patient-doctor communication for different types of requests (medical, administrative, etc.). ${ }^{10}$

Although in April 2016 the company implemented end-to-end encryption, there is still concern regarding the risks in terms of privacy, confidentiality, consent, and medicallegal matters in its use for patient-doctor communication. Guidelines for the appropiate use of WhatsApp Messenger for telemedicine and its integration with electronic medical records are required. ${ }^{11,12}$

WhatsApp Messenger has demonstrated it is useful to improve communication among health care providers due to its reduced costs, increased effectiveness, and communication availability, and because it has broken down the historical barriers between physicians working at different levels. ${ }^{13}$

Although its use has not been officially regulated, some countries have started making recommendations. The National Health Service of England has recently issued guidance on this and has pointed out that WhatsApp Messenger should not be used to share medical information. ${ }^{14}$

\section{E-mail}

E-mail is the most traditional way of electronic communication. It is inexpensive, dynamic, and effective. It is less invasive than messaging services because it is asynchronous, which allows physicians to answer later on.

However, since it is not custom-designed for medical use, it becomes tiresome to copy the exchanged information in the electronic medical record. In addition, e-mails do not meet security requirements because data are not duly encrypted. 
E-mail-mediated communication has been extensively studied by Daniel Sands, M.D., who described, in his portal, a basic agreement model that could be established with patients to give it an adequate framework. ${ }^{15}$ Some recommendations were taken and adapted to the use of other technologies (see Table 1).

A recent review concluded that, although e-mail is an extremely sensitive tool, it has not reached the expected levels of patient-doctor communication. Such delay may be due to the specific characteristics of each patient and doctor and the barriers in terms of fees, confidentiality, and security. ${ }^{16}$

\section{Patient portals}

Patient portals are defined as a secure web application that patients can use to access their health information from any Internetconnected device. In turn, it provides information on immunization, lab results, and prescribed medications. Some portals offer the option to schedule appointments and contact physicians online..$^{17,18}$

According to recent statistics, the number of pediatricians' portals in the United States of America increased from 633 to 17128 between 2008 and 2014. The most commonly used functions were messaging $(62.6 \%)$, lab results $(35.3 \%)$, and scheduling an appointment $(21.2 \%){ }^{19}$

A recently published longitudinal study was the first one to analyze patients' behavior over a 10-year period (2001-2010) in a patient portal from a Boston medical facility. A total of 49778 patients and 272 physicians from different specialties took part. It was observed that patients' consultations via electronic means trebled in the first 5 years (early adopters); then they reached a plateau, which allowed physicians to alternate between face-to-face visits and online consultations.

The average number of messages steadied at 18.9 messages per physician per month; $37.5 \%$ were sent outside business hours and, of these, $10 \%$ were sent during the weekend.

That study concluded that an innovative payment model including this practice should be developed. ${ }^{20}$

Patient-doctor interactions in the setting of a patient portal help to solve several of the current problems:

- Security and confidentiality: interaction takes place in a protected and encrypted web environment.

- Privacy: both patients and physicians should identify themselves in the system using some validation method.

- Medical-legal matters: any exchanged message is automatically integrated into the electronic medical record.

- Financial reimbursement: the portal could implement strategies for the reimbursement of these consultations, as agreed among the physician, the patient, and the financer.

\section{Advantages and disadvantages of patient- doctor communication via electronic messaging}

Generally speaking, electronic means as a whole pose great advantages ${ }^{21}$ for communication with patients because they:

- Are fast.

- Are accessible from any device (smartphone, tablet, personal computer).

- Avoid conversations.

- Help to keep a smooth communication outside business hours.

- Help to resolve administrative issues (appointments) and read supplementary test results.

- Know no geographic boundaries.

- Facilitate consultation with colleagues and interchanges with other physicians in different locations and levels.

- Reduce visit length.

- Are inexpensive.

- Overcome telephone contact barriers because several messages may be received at the same time.

However, and in spite of this, electronic means have certain disadvantages: ${ }^{21}$

- They are invasive.

- They may lead to misunderstandings due to typos or interpretation errors.

- They do not warrant privacy and confidentiality of transferred medical information.

- They may lead to medical-legal claims without an adequate insurance coverage.

- Consultations made using these means are not usually covered by reimbursement policies.

According to the world Health Organization (WHO), telemedicine is "the delivery of health care services, where distance is a critical factor, by all health care professionals using information and communication technologies for the exchange of valid information for diagnosis, treatment and prevention of disease and injuries, research and evaluation, and for the continuing education 
of health care providers, all in the interests of advancing the health of individuals and their communities." 22

When used correctly, telemedicine has the potential for improving the patient-doctor relationship with more opportunities to communicate and an easier access for both parties. ${ }^{23}$

As in every field of medicine, the patientdoctor relationship should be based on mutual respect, independence of opinion on part of the physician, patient autonomy, and professional confidentiality. ${ }^{24}$

From this perspective, each health care provider has the option to adopt the electronic messaging tools that he/she finds comfortable and beneficial for his/her practice and communication with patients.

\section{Recommendations for the inclusion of information and communication technologies in the doctor-patient relationship}

It is critical to establish, from the beginning, an adequate framework for this type of consultations. Then, standard requirements regarding the security, confidentiality, and privacy of medical information transactions, and an adequate medical-legal framework should be defined. ${ }^{25}$

The rights and obligations of each party should be agreed between the physician and the families; the recommendations in Table 2 may be used to this end.

While an ICT-mediated consultation is a medical act in addition to or supplementary of face-to-face visits, it is necessary to define reimbursement strategies to make it financially sustainable. ${ }^{4,28,29}$ There are several examples of the implementation of these measures globally. 30,31

Survey-based studies showed that both patients and health care delivery organizations were willing to pay for this service given that they had confirmed it was cost saving and increased effectiveness. ${ }^{32}$

\section{Legal considerations}

In the process of ICTs becoming massively used in the patient-doctor relationship, it is critical to establish an adequate legal framework to provide the necessary security to all parties involved in these new ways of communication.

Legal matters develop at a notably slower pace than technological advances; so, in spite of the intensive use of ICTs and the ongoing advances in telemedicine, there is still no specific regulatory framework for this in Argentina.

The regulatory gap is not an obstacle for the use of ICTs in medical communication, but it does call for the need to establish the responsibilities that rise from their use.

In Argentina, the following regulations could be considered for application, by analogy to digital medicine: articles 53, 55 (Right of publicity), 58 and 59 (Informed consent) of the National Civil and Commercial Code; article 153 of the Criminal Code (Violation of electronic communication); the Protection of Personal Information Act no. 25326; the Patient Rights Act no. 26529 and Decree 1089/2012; and the Digital Signature Act no. 25506.

TABLE 2. Recommendations for an adequate use of information and communication technologies in the communication with patients (adapted from the authors of references 26 and 27)

- Agree with patients on turnaround times for messages. Do not use this type of communication for urgent matters.

- Establish the days and times you will be available to answer questions made via these means.

- Agree with patients on what types of subject matters you will accept and manage electronically (e.g., images, videos, documents, X-rays, etc.).

- Inform patients about privacy issues. Patients should know (if applicable) who else may have access to their messages.

- These communications should be included in the medical record.

- Instruct patients to indicate a category in the subject line of their messages: prescription, appointment, medical advice, etc.

- Do not use these means of communication for matters that may affect the privacy of the patients or their families.

- Request that patients put their name, last name, and age in the body of the message.

- Consider using an exclusive e-mail account for virtual consultations. If so, include a footnote text detailing the terms and conditions regulating such consultations.

- Read receipt:

- E-mail: an automatic reply may be configured to alert patients that their message was received and that it will be answered within a specific period of time.

- Instant messaging: the most popular applications (WhatsApp Messenger) allow to configure read receipt checks.

- Agree with patients on expected response times during business hours, after hours, and on weekends.

- Never forward images or messages that include patient-identifiable information without patient permission. 
The transmission of images, conversations or voice messages among the "virtual" pediatrician/ family/patient triad should be framed within the legal regulations in place, in the first place, given their legislation hierarchy according to the National Civil and Commercial Code; in this regard, it is worth noting that article 53 establishes that it is necessary to obtain an individual's consent to "take or show / play a picture or the voice of a person".

The Protection of Personal Information Act (25326) considers that health information is sensitive data and, as such, deserves special treatment in terms of the implementation of tools that warrant security and confidentiality. To this end, whatever the means of communication (e-mail, WhatsApp Messenger, SMS, etc.), each one should comply with minimum security standards that at least safeguard sensitive data and provide for the inalterability and durability of medical records.

An aspect that should be considered in virtual pediatric relationships is that of the legal and probative value of digital communications.

The nature of "permanent" is one of the basic requirements for any virtual communication to be considered a "document," i.e., for it to have certain legal virtuality and be considered "authentic." For this to occur, it should be possible to obtain and/or retrieve any message or communication support at any time or, at least, the information should have a "print" that could be effectively tracked. ${ }^{33-37}$

\section{COMMENT}

Delbanco, M.D. and Sands, M.D. propose that, in the future, electronic communication in the field of medicine will consist in a patient-controlled medical record with access to synchronous and asynchronous communication with the physician, videoconferences, simultaneous translation to different languages, and connection to different sources of information and multimedia educational material. Electronic communication will also send home monitoring system data to primary care physicians. "Electronic communication will move medicine inexorably toward such transparency, enabling doctors and patients to share knowledge, responsibility, and decision making more equally. We need to explore rapidly how this change will affect the quality of care for patients, and the quality of life for doctors." 15,38

ICTs are here to stay and have radically transformed the health care process. Scientific societies and associations are responsible for promoting the establishment of adequate standards for this type of consultation. ${ }^{24}$

Time after time, it has been said that medicine is the most humane of sciences and the most scientific of humanities. The use of ICTs should be covered by such definition. It is not a matter of technophobia or technologism but, in Aristotelian terms, a matter of the golden mean: we should master technology without turning into its slaves. A harmonized Hippocratic medical model with a digital health care system will result in humane, secure, and good-quality patient-doctor relationships.

\section{Acknowledgments}

We would like to thank Paula Otero, M.D.

\section{REFERENCES}

1. Weiner JP. Doctor-patient communication in the e-health era. Isr J Health Policy Res 2012; 1(1):33.

2. Mobasheri MH, King D, Johnston M, et al. The ownership and clinical use of smartphones by doctors and nurses in the UK: a multicentre survey study. BMJ Innov Published Online First: 7 October 2015.Pages.1-8.

3. INDEC. Encuesta Nacional sobreAcceso y Uso de Tecnologías de la Información y la Comunicación (ENTIC). Buenos Aires: Ministerio de Economía y FinanzasPúblicas; 2015. [Accessed on: January 25th, 2018]. Available at: http: / / www.indec.gov.ar/ uploads/informesdeprensa / entic_10_15.pdf.

4. Brown J. How to master electronic communication with patients. Med Econ 2013; 90(7):60-2, 64-7.

5. DroletBC. TextMessaging and Protected Health Information: What Is Permitted? JAMA 2017; 317(23):2369-70.

6. Veneni L, Ferrari A, Acerra S, et. al. Considerazionisull'uso di WhatsApp nellacomunicazione e relazione medicopaziente. Recenti Prog Med 2015; 106(7):331-6.

7. Blog de Whatsapp. Conectando mil millones de usuariostodoslosdías. [Accessed on: November 7th, 2017]. Available at: https://blog.whatsapp.com/10000631/ Conectando-mil-millones-de-usuarios-todos-los$\mathrm{d} \% \mathrm{C} 3 \%$ ADas.

8. Ganasegeran K, Renganathan P, Rashid A, et al. The m-Health revolution: Exploring perceived benefits of WhatsApp use in clinical practice. Int J Med Inform 2017; 97:145-51.

9. Raiman L, Antbring R, Mahmood A. WhatsApp messenger as a tool to supplement medical education for medical students on clinical attachment. BMC Med Educ 2017; 17(1):7.

10. Giordano V, Koch H, Godoy-Santos A, et al. WhatsApp Messenger as an Adjunctive Tool for Telemedicine: An Overview. Interact J Med Res 2017; 6(2):e11.

11. Mars M,ScottRE. WhatsAppin Clinical Practice:ALiterature Review. Stud Health Technol Inform 2016; 231:82-90.

12. Drake TM, Claireaux HA, Khatri C, et al. WhatsApp with patient data transmitted via instant messaging? Am J Surg 2016; 211(1):300-1.

13. Gulacti U, Lok U, Hatipoglu S, et al. An Analysis of WhatsApp Usage for Communication Between Consulting and Emergency Physicians. J Med Syst 2016; 40(6):130. 
14. Georgina Gould, RaminNilforooshan. WhatsApp, Doc? BMJ Innov 2016; 2:109-10.

15. Delbanco T, Sands D. Electrons in Flight - E-Mail between Doctors and Patients. N Engl J Med 2004; 350(17):1705-7.

16. Antoun J. Electronic mail communication between physicians and patients: a review of challenges and opportunities. Fam Pract 2016; 33(2):121-6.

17. Tang PC, Ash JS, Bates DW, et al. Personal Health Records: Definitions, Benefits, and Strategies for Overcoming Barriers to Adoption. J Am Med Inform Assoc 2006; 13(2):121-6.

18. Health IT.gov. What is a patient portal? [Accessed on: November 6th, 2017]. Available at: https: / / www.healthit. gov/providers-professionals / faqs/ what-patient-portal.

19. Steitz B, Cronin RM, Davis SE, et al. Long-term Patterns of Patient Portal Use for Pediatric Patients at an Academic Medical Center. Appl Clin Inform 2017; 8(3):779-93.

20. Crotty BH, Tamrat Y, Mostaghimi A, et al. Patient-ToPhysician Messaging: Volume Nearly Tripled As More Patients Joined System, But Per Capita Rate Plateaued. Health Aff (Millwood) 2014; 33(10):1817-22.

21. Houston TK, Sands DZ, Jenckes MW, et al. Experiences of patients who were early adopters of electronic communication with their physician: satisfaction, benefits, and concerns. Am J Manag Care 2004; 10(9):601-8.

22. World Health Organization. Telemedicine: Opportunities and developments in member states. Report on the second global survey on eHealth. Geneva: WHO; 2010. [Accessed on: January 25th, 2018]. Available at: http:/ / www.who. int/goe/publications/goe_telemedicine_2010.pdf.

23. Peleg R, Nazarenko E. Providing cell phone numbers and e-mail addresses to patients: The patient's perspective, a cross sectional study. Isr J Health Policy Res 2012; 1(1):32.

24. AsociaciónMédica Mundial. Declaración de la AAM sobre las Responsabilidades y NormasÉticasen la Utilización de la Telemedicina. [Accessed on: November 7th, 2017]. Available at: https:/ / www.wma.net/es/policies-post/ declaracion-de-la-amm-sobre-las-responsabilidades-ynormas-eticas-en-la-utilizacion-de-la-telemedicina/.

25. Dash J, Haller DM, Sommer J, et al. Use of email, cell phone and text message between patients and primarycare physicians: cross-sectional study in a French-speaking part of Switzerland. BMC Health Serv Res 2016; 16(1):549.

26. Kane B, Sands DZ. Guidelines for the Clinical Use of Electronic Mail with Patients. J Am Med Inform Assoc 1998; 5(1):104-11.

27. American Medical Association. Guidelines for physicianpatient electronic communication. [Accessed on: January 25th, 2018]. Available at: http: / / www.amaassn.org/ama / pub/about-ama/our-people/member-groups-sections / young-physicianssection/advocacyresources / guidelinesphysician-patient-electronic-communications.shtml.

28. Landon BE. Keeping Score under a Global PaymentSystem. N Engl J Med 2012; 366(5):393-5.

29. American College of Physicians. The Changing Face of Ambulatory Medicine-Reimbursing Physicians for Computer-BasedCare:ACPAnalysisand Recommendations to Assure Fair Reimbursement for Physician Care Rendered Online. Philadelphia:American College of Physicians; 2003: Policy Paper. [Accessed on: January 25th, 2018]. Available at: https:/ / www.acponline.org/acp_policy/policies / ambulatory_medicine_reimbursements_computer_ based_care_2003.pdf.

30. Antoun J. Electronic mail communication between physicians and patients: a review of challenges and opportunities. Fam Pract 2016; 33(2):121-6.

31. Rutland J, Marie C, Rutland B. A system for telephone and secure email consultations, with automatic billing. J Telemed Telecare 2004; 10(Suppl 1):88-91.

32. Komives EM. Clinician-patient E-mail communication: challenges for reimbursement. N C Med J 2005; 66(3):23840.

33. Molina Quiroga E. Documentos y comunicaciones electrónicas: su eficacia probatoria a la luz del Código Civil y Comercial. Dossier: Derecho Informático. Jurisprudencia Argentina 2017; 2(9):36-60.

34. Wierzba S. Derecho a la imagen: Impresiones entorno a su regulaciónen el nuevo Código Unificado. In Temas de Derecho Civil. Persona y Patrimonio. Buenos Aires: Errepar; 2016.Pages.39-68.

35. VítoloF. Telemedicina,NuevasTecnologías, NuevosRiesgos. Biblioteca Virtual NOBLE. Octubre 2011:1-13. [Accessed on: January 8th, 2018]. Availableat:http: / / www.nobleseguros. $\mathrm{com} / \mathrm{blog} /$.

36. Vítolo F. Mucho más que un software: el Modelo SocioTécnico de la Informatización en Salud. Biblioteca Virtual NOBLE. Abril 2016:1-9. [Accessed on: January 8th, 2018]. Available at: http:/ / www.nobleseguros.com/blog/.

37. Vítolo F. Celulares, Tablets y Dispositivos Electrónicos personales en Instituciones de Salud, conozca los riesgos. Biblioteca Virtual Noble. Septiembre 2016:1-18. [Accessed on: January 8th, 2018]. Available at: http://www. nobleseguros.com/blog/.

38. Society for Participatory Medicine. Newburyport, 2017. [Accessed on: November 20th, 2017]. Available at: https: / / participatorymedicine.org/. 